\title{
Kajian Penggunaan Nutrisi Anorganik Terhadap Pertumbuhan Kangkung (Ipomoea reptans Poir) Hidroponik Sistem Wick
}

\section{Study of the Use of Inorganic Nutrition on the Growth of Kale (Ipomoea reptans Poir) Wick Hydroponics System}

\author{
Nurul Hidayati ${ }^{1}$, Pienyani Rosawanti ${ }^{1}$, Fitriadi Yusuf ${ }^{1}$ dan Nanang Hanafi ${ }^{2}$ \\ 1. Staf Pengajar Program Studi Agroteknologi ,2. Staf Pengajar Program Studi Kehutanan Fakultas \\ Pertanian dan Kehutanan Universitas Muhammadiyah Palangkaraya \\ Email : nurul.hidayati@umpalangkaraya.ac.id
}

\begin{abstract}
This study aims to determine the effect of giving different types of nutrients on the growth of kale in hydroponic wick system. The study was a single factor experiment with two treatments using Completely Randomized Design (CRD) with 7 replications. The treatment given was inorganic fertilizer AB Mix and NPK plus inorganic fertilizer. Nutritional concentration was given as much as $10 \mathrm{ml} /$ liter.

The results showed that the type of nutrient treatment was significantly affected the growth of plant height at age 14 days after planting (DAP) and 21 DAP. At age 28 DAP there was no real effect. The producing of leaves number was differences at all stages. Provision of nutrition AB mix produced higher plant height at 14 DAP $(15.9 \mathrm{~cm})$ and 21 DAP $(19.3 \mathrm{~cm})$. Parameter of leaf number, AB mix yield more leaves at 14 hst $(8,1$ strand), 21 hst (11,1 strands) and 28 DAP (13,4 strands) respectively.
\end{abstract}

Keywords: Inorganic nutrition, kale, hydroponics, wick system

\begin{abstract}
Abstrak
Penelitian ini bertujuan untuk mengetahui pengaruh pemberian jenis nutrisi yang berbeda terhadap pertumbuhan tanaman kangkung secara hidroponik sistem wick.

Penelitian ini merupakan percobaan faktor tunggal dengan 2 perlakuan dengan menggunakan Rancangan Acak Lengkap (RAL) dengan 7 ulangan. Perlakuan yang diberikan pupuk anorganik AB Mix dan pupuk anorganik NPK plus. Konsentrasi nutrisi yang diberikan sebanyak $10 \mathrm{ml} / \mathrm{liter}$.

Hasil penelitian menunjukkan perlakuan jenis nutrisi berpengaruh nyata pada parameter pertumbuhan tinggi tanaman pada umur 14 hari setelah tanam (hst) dan 21 hst. Pada umur 28 hst tidak menunjukkan pengaruh nyata. Parameter jumlah daun yang dihasilkan menunjukkan perbedaan pada semua umur. Nutrisi $\mathrm{AB}$ mix menghasilkan tinggi tanaman yang lebih banyak pada umur $14 \mathrm{hst}(15,9 \mathrm{~cm})$ dan $21 \mathrm{hst}(19,3 \mathrm{~cm})$. Parameter jumlah daun, $\mathrm{AB}$ mix menghasilkan daun yang lebih banyak pada umur 14 hst $(8,1$ helai) dan 21 hst (11,1 helai) dan 28 hst ( 13,4 helai)
\end{abstract}

Kata Kunci : Nutrisi anorganik, kangkung, hidroponik, sistem wick

\section{PENDAHULUAN}

\subsection{Latar Belakang}

Kangkung merupakan jenis sayuran yang banyak digemari masyarakat, kandungan zat gizinya tinggi, dan budidayanya sangat sederhana serta mudah. Kandungan gizi kangkung cukup tinggi terutama vitamin $\mathrm{A}$, vitamin $\mathrm{C}$, zat besi, kalsium, potasium, dan fosfor 
(Sofiari, 2009). Kandungan gizi dalam setiap 100 gram sayuran kangkung mengandung energi : $29 \mathrm{kkal}$, protein : 3 gr, lemak : 0,3 gr, karbohidrat : 5,4 gr, kalsium : $73 \mathrm{mg}$, fosfor : $50 \mathrm{mg}$, zat besi : $3 \mathrm{mg}$, vitamin A: $6300 \mathrm{IU}$, vitamin B1 : 0,07 $\mathrm{mg}$, vitamin $\mathrm{C}: 32 \mathrm{mg}$.

Menurut Teguh Sutanto (2015) bahwa dengan budidaya secara hidroponik dapat dilakukan dalam ruang yang sempit, media tanam dapat diatur secara vertikal. Pada tanaman hidroponik juga dapat memberikan kesan design interior yang bagus dan menarik untuk digunakan sebagai hiasan di rumah. Banyak sebagian orang tidak mengetahui tentang apa itu hidroponik, dan bagaimana cara menanamnya. Pada sistem penanaman hidroponik, nutrisi pada pupuk hidroponik harus mengandung unsur makro dan unsur mikro yang banyak dibutuhkan oleh tanaman. Dalam menanam hidroponik juga ada aspek-aspek yang perlu diperhatikan untuk menunjang tanaman hidroponik seperti air, media tanam, unsur hara dan oksigen. Tanaman secara hidroponik ini juga sangat ramah lingkungan, tidak menggunan pestisida yang dapat merusak tanah dan tidak menimbulkan banyak polusi.

Kangkung yang diperbanyak secara hidroponik banyak mempunyai kelebihan, selain lebih bersih dari teknik konvensional (menggunakan media tanah), pemanenan kangkung dapat dipotong, dan sisa batang akan tumbuh menjadi tajuk baru yang dapat dipanen lagi dalam waktu 10 minggu setelah panen pertama dan hasilnya tetap tinggi. Hal ini karena suplai nutrisi yang terpenuhi, sehingga perkembangan tajuk masih dapat maksimal. Penggunaan sistem hidroponik dalam budidaya ini diharapkan dapat meningkatkan pertumbuhan dan hasil tanaman kangkung.

Budidaya hidroponik kangkung sistem wick (sumbu), sumbu yang digunakan bisa dari sumbu kompor, kapas, kain bekas bahkan kain flanel yang terpenting bahan sumbu bisa menyerap air. Akar tanaman tidak dicelupkan langsung ke dalam air, melainkan mereka tumbuh dalam beberapa bahan penahan air seperti rockwool, busa atau cocopeat.

Dalam hidroponik nutrisi merupakan faktor utama yang menentukan keberhasilan budidaya tanaman secara hidroponik. Larutan yang ada pada media harus kaya akan nutrisi untuk pertumbuhan. Menurut Lingga (2006) bahwa pada pertumbuhan vegetatif tanaman, yang ditunjukkan dengan pertambahan panjang, tinggi, unsur hara yang berperan adalah nitrogen $(\mathrm{N})$ yang 
berfungsi untuk memacu pertumbuhan pada fase vegetatif terutama daun dan batang

Aspek penting yang perlu diperhatikan dalam menentukan keberhasilan budidaya hidroponik adalah pengelolaan tanaman yang meliputi persiapan bahan media, larutan nutrisi, pemeliharaan, aplikasi larutan nutrisi, panen dan pasca panen (Rosikiana R. dan Sumarni N, 2005).

Untuk mengetahui efektivitas pupuk anorganik hidroponik di pasaran dan pupuk anorganik yang dibuat dari pupuk-pupuk tanaman budidaya konvensional, dilakukan penelitian ini.

\subsection{Tujuan}

Tujuan percobaan adalah untuk mengetahui efektivitas jenis pupuk yang diberikan dengan dosis yang sama terhadap pertumbuhan tanaman kangkung secara hidroponik.

\subsection{Hipotesis}

Perbedaan jenis pupuk anorganik yang digunakan akan menghasilkan pertumbuhan kangkung yang berbeda.

\section{METODE PENELITIAN}

\subsection{Tempat dan Waktu}

Penelitian dilaksanakan di Jalan RTA Milono Kampus Universitas Muhammadiyah Palangkaraya.
Penelitian dilakukan selama 3 (tiga) bulan.

\subsection{Bahan dan Alat}

Bahan bahan yang digunakan untuk penelitian ini rockwool, sekam, benih kangkung, nutrisi AB Mix Daun Ijo, Pupuk NPK + pupuk daun gandarsil yang dicairkan.

Alat yang digunakan yaitu paralon, EC meter, gelas ukur, ember, meteran, kamera, parang, dan alat tulis.

\subsection{Metode Penelitian}

Metode penelitian ini menggunakan Rancangan Acak Lengkap (RAL) faktor tunggal. Perlakuan jenis nutrisi yaitu AB Mix dan NPK Plus. Setiap perlakuan terdiri dari 16 tanaman, sehingga terdapat 32 unit perlakuan .

\subsection{Pelaksanaan Penelitian}

\section{Persiapan Nutrisi}

Tempat tanam berupa paralon panjang 5 meter dengan lubang tanam sebanyak 16 lubang, sebanyak 2 bı masing-masing perlakuan pada satu paralon. Satu Paralon diisikan air nutrisi sebanyak 5 liter dengan konsentrasi yang sama $10 \mathrm{ml} / \mathrm{liter}$. 
Benih direndam 15 menit disemaikan pada rockwool, setelah 3 hari dipindahkan pada paralon yang sudah disiapkan. Penambahan air nutrisi disamakan, penambahan air awal setelah satu minggu setelah tanam. Tanaman umur 14 hari ke atas, 2 hari sekali diperiksa air nutrisinya karena penyerapannya sangat cepat sekali. Jumlah larutan nutrisi yang diberikan pada semua paralon sama. Total larutan nutrisi yang diberikan mulai tanam sampai panen 35 liter per paralon.

\subsection{Variabel Pengamatan}

a. Tinggi tanaman, diukur mulai dari leher akar sampai titik tumbuh tanaman. Pengamatan tinggi tanaman diukur pada umur 14 hst, 21 hst dan 28 hst.

b. Jumlah daun per tanaman, dihitung pada umur 14 hst, 21 hst dan 28 hst.

\subsection{Analisis Data}

Data hasil pengamatan dianalisis menggunakan analisis ragam (uji F) pada taraf $\alpha=1 \%$ dan $5 \%$. Apabila Uji F menunjukan adanya pengaruh perlakuan, maka dilanjutkan dengan $\mathrm{Uji}$ BNJ taraf $5 \%$.

\section{HASIL DAN PEMBAHASAN}

\subsection{Hasil Penelitian}

Dari hasil penelitian diperoleh data rerata tinggi tanaman dan rerata jumlah daun, yang dilakukan analisis ragam dengan uji F. Hasil analisis ragam, perlakuan berpengaruh nyata pada parameter tinggi tanaman pada umur $14 \mathrm{hst}$ dan 21 hst, sedangkan pada parameter jumlah daun, perlakuan berpengaruh nyata pada setiap pengamatan. Hasil uji beda rata-rata tinggi tanaman dan jumlah daun terdapat pada Tabel 1 dan Tabel 2.

Tabel 1. Hasil uji beda rata-rata tinggi tanaman kangkung

\begin{tabular}{llll}
\hline Perlakuan & 14 hst & 21 hst & 28 hst \\
\hline AB mix & $15,9 \mathrm{~b}$ & $19,3 \mathrm{~b}$ & $27,5 \mathrm{a}$ \\
NPK Plus & $12,7 \mathrm{a}$ & $15,6 \mathrm{a}$ & $27,4 \mathrm{a}$ \\
\hline
\end{tabular}

Keterangan: Angka-angka yang didampingi notasi yang sama pada kolom yang sama tidak berbeda nyata pada uji BNJ 5\%

Hasil uji beda rata-rata pada Tabel 1 menunjukkan perlakuan nutrisi $\mathrm{AB}$ mix berbeda nyata dari nutrisi NPK plus pada parameter tinggi tanaman kangkung umur
14 hst dan 21 hst, sedangkan pada 28 hst tidak berpengaruh nyata pada parameter tinggi tanaman kangkung. 
Tanaman Kangkung menggunakan $\mathrm{AB}$ mix lebih tinggi dibandingkan NPK plus pada umur 14 hast dan 21 hst, untuk umur 28 hst atau pada saat panen tidak menunjukkan perbedaan.

Tabel 2. Hasil uji beda rata-rata jumlah daun tanaman kangkung

\begin{tabular}{llll}
\hline Perlakuan & $14 \mathrm{hst}$ & $21 \mathrm{hst}$ & $28 \mathrm{hst}$ \\
\hline AB mix & $8,1 \mathrm{~b}$ & $11,1 \mathrm{~b}$ & $13,4 \mathrm{~b}$ \\
NPK Plus & $5,9 \mathrm{a}$ & $8,3 \mathrm{a}$ & $10,8 \mathrm{a}$ \\
\hline
\end{tabular}

Keterangan : Angka-angka yang didampingi notasi yang sama pada kolom yang sama tidak berbeda nyata pada uji BNJ 5\%

Hasil uji beda rata-rata jumlah daun pada Tabel 2 menunjukkan perlakuan nutrisi $\mathrm{AB}$ mix berbeda nyata dari nutrisi NPK plus pada parameter jumlah daun tanaman kangkung umur 14 hst 21 hst, dan 28 hst.

Jumlah daun kangkung dihasilkan oleh perlakuan nutrisi $\mathrm{AB}$ mix lebih banyak pada semua umur tanaman, hingga saat panen.

Penggunaan dosis nutrisi 10 $\mathrm{ml} /$ liter untuk kedua perlakuan tersebut, mulai tanam sampai panen. Pertimbangan tanaman kangkung merupakan tanaman yang di konsumsi pada fase vegetatif.

\subsection{Pembahasan}

Pada pengamatan umur 14 hst dan 21 hst pertumbuhan tanaman menunjukkan perbedaan pada rata-rata tinggi tanaman dan jumlah daun. Pada pengamatan tinggi tanaman umur 28 hst menunjukkan perlakuan tidak berbeda nyata. Pada parameter jumlah daun pada setiap umur pengamatan yaitu 14, 21 dan 28 hst menunjukan perbedaan. Keperluan nutrisi tersedia pada pupuk AB mix lebih tercukupi dibanding pupuk NPK plus. Pupuk $\mathrm{AB}$ mix merupakan pupuk yang diproduksi oleh pabrik, sedangkan pupuk NPK plus merupakan pupuk olahan alternatif sebagai pengganti pupuk hidroponik, yang susah didapatkan di pasaran. Khususnya untuk daerah yang aksesnya masih belum terjangkau.

Larutan hidroponik yang ada pada media harus kaya akan nutrisi untuk pertumbuhan. Pada pertumbuhan vegetatif tanaman yang ditunjukkan dengan pertambahan panjang, unsur hara yang berperan adalah nitrogen $(\mathrm{N})$ yang berfungsi untuk memacu pertumbuhan pada fase vegetatif terutama daun dan batang (Lingga, 2006).

Dari hasil penelitian bahwa menggunakan pupuk NPK plus untuk tinggi tanaman pada umur 28 hst atau pada 
saat panen tidak berbeda dengan pupuk $A B$ mix, yang berarti pupuk NPK plus masih layak digunakan.

Sebenarnya menanam kangkung hidroponik sistem wick pada sistem hidroponik statis lebih menguntungkan sebab mudah dalam perawatannya dan tidak perlu melakukan penyiraman. Sistem wick atau sistem sumbu merupakan teknik hidroponik yang sangat sederhana sebab hanya menggunakan prinsip kapilaritas air, yaitu larutan nutrisi yang berasal dari paralon penampungan mengalir menuju perakaran tanaman.

Menurut Teguh Sutanto (2015) bahwa air yang digunakan untuk hidroponik harus memiliki $\mathrm{pH}$ yang sesuai dengan tingkat keasaman. $\mathrm{pH}$ anjuran kisaran $5.5-6.5 . \mathrm{pH}$ di bawah 5.5 beberapa unsur hara akan mngendap dan tidak dapat terserap oleh akar.

Pada Penelitian ini menggunakan air sumur dengan $\mathrm{pH}$ 4,7. Daerah kota Palangka Raya sebagian besar lahan gambut sehingga air sumur yang digunakan masih masuk kriteria asam. Suhu pada saat penelitaan masih memenuhi suhu agrolimat tanaman kangkung yaitu kisaran $28-34{ }^{\circ} \mathrm{C}$

\section{KESIMPULAN DAN SARAN}

\subsection{Kesimpulan}

1. Pengaruh penggunaan pupuk $A B$ mix lebih menunjukkan pertumbuhan yang lebih baik dilihat dari parameter tinggi tanaman dan jumlah daun dibandingkan pupuk NPK plus.

2. Dosis pupuk $A B$ mix dengan dosis $10 \mathrm{ml} /$ liter mencukupi untuk pertumbuhan kangkung hidroponik mulai tanam sampai panen.

\subsection{Saran}

1. Penggunaaan pupuk $A B$ mix untuk hidroponik dianjurkan, tetapi apabila tidak tersedia di pasaran masih dapat menggunakan pupuk NPK plus, karena tinggi tanaman saat panen (umur $28 \mathrm{hst)}$ tidak berbeda dengan hasil nutrisi $\mathrm{AB}$ mix

2. Penelitian lanjutan tentang hidroponik untuk tanaman penghasil buah.

\section{UCAPAN TERIMA KASIH}

Penulis menyampaikan ucapan terima kasih kepada Kepala Lembaga penelitian dan pengabdian (LPPM), Dekan Fapertahut, Prodi Agroteknologi dan Prodi Kehutanan Fapertahut Universitas Muhammadiyah Palangkaraya serta semua pihak yang sudah berkontribusi dalam kegiatan ini dan tidak memungkinkan disebutkan satu per satu. 


\section{DAFTAR PUSTAKA}

Arifin, A. 1990. Hortikultura Tanaman Buah-Buahan, Sayuran dan Tanaman Bunga Hias. Andi Offset. Yogyakarta.

Gardner, F.P., R.B. Pearce, Hoger L. M., 1991, Fisiologi Tanaman Budidaya (tercemahan), UIPress, Jakarta.

Indrawati, R., D. Indradewa dan S.N.H. Utami, 2012. Pengaruh Komposisi Media dan Kadar Nutrisi Hidroponik Terhadap Pertumbuhan dan Hasil Tomat (Lycopersicon esculentum Mill). UGM, Yogyakarta.

Lingga, P., 2006. Hidroponik Bercocok Tanam Tanpa Tanah. Penebar Swadaya, Jakarta.

Mas'ud, Hidayati, 2009. Sistem Hidroponik dengan Nutrisi dan Media Tanam Berbeda terhadap Pertumbuhan dan Hasil Selada. Program Studi Budidaya Pertanian. Fakultas Pertanian. Universitas Tadulako. Palu.

Nichollis, R. E. 1989, Hidroponik Tanaman Tanpa Tanah, Efhar dan Dahara Prize, Jakarta.

Perwitawati, B, M. Tripatmasari dan C. Wasonowati, 2012. Pengaruh Media Tanam dan Nutrisi Terhadap Pertumbuhan dan Hasil Tanaman Pakchoi (Brassica juncea L.) dengan Sistem Hidroponik. Jurnal Agrovigar Vol. 5 No. 1 Universitas Trunojoyo Madura.

Rosliana, R dan N. Sumarni, 2005, Budidaya Tanaman Sayuran dengan sistem hidroponik, Jurnal Monografi No. 27.Balai Penelitian Tanaman Sayuran
Samanhudi dan D. Harjoko, 2006, Pengaturan Komposisi Nutrisi dan Media Dalam Budidaya Tanaman Tomat Dengan Sistem Hidroponik. UNS, Surakarta

Siswadi dan Teguh Yuwono, 2013, Uji Hasil Tanaman Sawi Pada Berbagai Media Tanam Secara Hidroponik. Jurnal Innofarm Vol. II, No. 1, 4450.

Sitompul, S.M. dan B. Guritno.1995. Analisis Pertumbuhan Tanaman. Gadjah Mada University Press.Yogyakarta.

Soeseno, S. 1988. Bercocok Tanam Secara Hidroponik. Gramedia : Jakarta.

Sofiari, E. 2009.KarakterisasiKangkung varietas sutera berdasarkan panduan pengujian individual. Buletin Plasma Nutfah, 15(2): 4950.

Susilo, A. D. dan Koesniawati, 2004. Pengaruh Volume dan Jenis Media Tanam pada Pertumbuhan dan Hasil Tanaman Selada (Lactuca sativa) dalam Teknologi Hidroponik Sistem Terapung, Buletin Agron (32) (3) 1621. 